\title{
O núncio Alessandro Bavona e a criação da província eclesiástica de Cuiabá em 1910
}

\section{The nuncio Alessandro Bavona and the creation of the ecclesiastical province of Cuiabá in 1910}

\author{
Jérri Roberto Marin* \\ https://orcid.org/0000-0003-0882-1359
}

\begin{abstract}
Resumo
Este artigo analisa as políticas e estratégias da Santa Sé para dividir o território da diocese de Cuiabá e elevá-la a arquidiocese, tendo como sufragâneas as dioceses de Cáceres e Corumbá. O estilo de mando do bispo D. Carlos Luiz d'Amour e sua atuação pouco eficaz, a grande extensão territorial da diocese e sua baixa densidade demográfica motivaram as intervenções da Santa Sé. A ampliação das circunscrições eclesiásticas em Mato Grosso tinha como objetivo tornar mais eficiente sua governabilidade, assegurar o controle e a regulação dos indivíduos e do corpo social, implementar as reformas internas, combater as religiões concorrentes e fortalecer a Igreja Católica perante o Estado. As fontes utilizadas foram obtidas no Arquivo Apostólico Vaticano e no Arquivo da Sagrada Congregação dos Trabalhos Eclesiásticos Extraordinários e permitiram compreender as articulações e projetos do núncio Alessandro Bavona e do secretário de Estado Raffaele Merry Del para reformar, fortalecer e expandir a Igreja Católica no Brasil.

Palavras-chave: Santa Sé; D. Carlos Luiz d'Amour; dioceses; Mato Grosso; Nunciatura Apostólica

Abstract

This article analyzes the policies and strategies of the Holy See to divide the territory of the diocese of Cuiabá and elevate it to the status of archdiocese, having as suffragans the dioceses of Cáceres and Corumbá. The style of mando of bishop Carlos Luiz d'Amour and his ineffective performance, the large territorial extent of the diocese and its low demographic density motivated the interventions of the Holy See. The expansion of ecclesiastical circumscriptions in Mato Grosso aimed to make their governability more efficient, ensuring
\end{abstract}

\footnotetext{
* Doutor em História pela Universidade Estadual Paulista (UNESP); Pós-doutor pela Università Degli Studi di Roma "La Sapienza"; Professor Titular da Faculdade de Ciências Humanas/Curso de História/Universidade Federal de Mato Grosso do Sul (UFMS); Professor da Pós-Graduação em História da Universidade Federal da Grande Dourados (UFGD). E-mail: jerrimarin@gmail.com.
} 
the control and regulation of individuals and the social body, implement internal reforms, combat competing religions and strengthen the Catholic Church before the State. The sources were obtained from the Vatican Apostolic Archives and the Historical Archive of the Congregation on the Extraordinary Ecclesiastical Affairs, that allow detailing the articulations and projects of the nuncio Alessandro Bavona and secretary of State Raffael Merry Del Val to reform, strengthen and expand the Catholic Church in Brazil.

Keywords: Holy See; D. Carlos Luiz d'Amour; dioceses; Mato Grosso; Nunciatura Apostólica

O objetivo deste artigo é analisar a criação da província eclesiástica de Cuiabá durante a gestão do bispo D. Carlos Luiz d'Amour (1878-1921), quando foram criadas as dioceses de Cáceres e Corumbá. ${ }^{1}$ Para tal, é necessário enfocar o cenário religioso de Mato Grosso e as macrorrelações envolvidas nesse processo, tais como as relações institucionais entre D. Carlos e a Santa Sé, a hierarquia eclesiástica brasileira e as tensões e os conflitos que permeavam o campo religioso católico. Pretende-se articular os percursos institucionais com a trajetória individual de D. Carlos. Para Elias, a sociedade é constituída por uma rede de funções que geram, na dinâmica social, uma interdependência entre os indivíduos:

Assim, cada pessoa singular está realmente presa; está presa por viver em permanente dependência funcional de outras; ela é um elo nas cadeias que ligam outras pessoas, assim como todas as demais, direta ou indiretamente, são elos nas cadeias que as prendem. Essas cadeias não são visíveis e tangíveis, como grilhões de ferro. São mais elásticas, mais variáveis, mais mutáveis, porém não menos reais, e decerto não menos fortes. E é a essa rede de funções que as pessoas desempenham umas em relação a outras, a ela e nada mais, que chamamos 'sociedade'.

\footnotetext{
${ }^{1}$ Uma complementação desse artigo, onde enfoco os impasses criados pelos carmelitas Calçados, que levaria à extinção da diocese de Corumbá, e a nomeação dos bispos para as novas dioceses, foi publicada na coletânea MARIN, Jérri Roberto (org.). Circunscrições eclesiásticas católicas no Brasil: articulações entre Igreja, Estado e sociedade. Campo Grande, Ed. da UFMS, 2021. Disponível em: https://repositorio.ufms. br/handle/123456789/3660.
}

${ }^{2}$ ELIAS, Norbert. A sociedade dos indivíduos. Rio de Janeiro: Jorge Zahar, 1994, p. 23. 
D. Carlos foi nomeado bispo da diocese de Cuiabá, tendo sido preconizado em 28 de dezembro de 1876 e confirmado no consistório de 21 de setembro de 1877. Foi sagrado bispo em 28 de abril de 1878, em Salvador, e tomou posse em 2 de maio de 1879. Anteriormente, havia sido secretário particular de D. Manoel Joaquim da Silveira, na diocese do Maranhão, e, posteriormente na arquidiocese de Salvador. Com o falecimento de D. Manoel, foi nomeado vigário capitular do arcebispado da Bahia, cargo que ocupou entre $1874 \mathrm{e}$ 1877. O patrocínio eclesiástico em sua formação, desde o período em que foi seminarista, e a proximidade e os laços de amizade com D. Manoel marcaram sua trajetória de vida, pois internalizou um estilo de mando aristocrático e autoritário, que valorizava as hierarquias. D. Carlos tinha uma personalidade forte, rígida, altiva e de difícil convívio social.

A ampliação da estrutura organizacional da Igreja Católica no Brasil está inserida no conjunto de reformas implantadas pela Santa Sé a partir de meados do século XIX. Os objetivos eram superar os problemas herdados do regime imperial, sobreviver diante das transformações advindas do regime republicano, reestruturar o funcionamento e a organização institucional, dinamizar sua presença no país, impor sua soberania sobre o Estado e combater a laicidade, a secularização, a crescente pluralização religiosa (expansão do protestantismo, do espiritismo e das religiões de matriz africana) e ideológica (positivismo, liberalismo, anarquismo, etc.). Após a proclamação da República intensificaram-se os esforços da Santa Sé para implantar uma ampla reorganização da Igreja Católica no Brasil a fim de ampliar o número de circunscrições eclesiásticas e, com isso, favorecer a melhoria da gestão do território e da população, pois quanto maior o território das dioceses (e das províncias eclesiásticas), maiores as dificuldades de vigiar e disciplinar o clero, de realizar visitas pastorais com frequência e de assistir a população. As dioceses extensas passaram a ser associadas à ineficiência e à má administração episcopal, que não se empenhava ou não queria dividir sua diocese. A Santa Sé desejava dividir as dioceses mais extensas e as mais populosas. De acordo com Marin:

A multiplicação e a reforma da estrutura organizacional, com a criação de arquidioceses, dioceses, prelazias, prefeituras apostólicas e missões, estavam associadas às políticas estratégicas para dinamizar a presença institucional e a importância na sociedade e frente ao Estado secular, ao ampliar sua inserção política, que permitiria legitimar-se frente ao Estado e pleitear o reconhecimento dos seus princípios. Dividir os territórios diocesanos 
possibilitava adotar novas tecnologias de poderes e de saberes, complementando e tornando mais eficazes as técnicas disciplinares, de esquadrinhamento e vigilância da população e dos indivíduos. Quanto menor o território, mais produtiva seria a gestão e maior o poder pastoral dos bispos para imporem normas, regulamentos, mecanismos disciplinares sobre a população, o clero e os fiéis, que eram individualizados, vigiados, mobilizados e eventualmente punidos. ${ }^{3}$

Os estudos sobre a criação de novas circunscrições eclesiásticas estão também se consolidando no Brasil. ${ }^{4}$ Os pesquisadores estão atentos às singularidades e às circunstâncias de cada diocese, pois as decisões episcopais não foram homogêneas e os bispos não eram "agentes de Roma", que seguiam fielmente as determinações papais e procuravam fortalecer a sua autoridade. Muitos deles tinham ideias próprias e resistiam às instruções e determinações de Roma. ${ }^{5}$

Atualmente, há discussões que questionam as interpretações historiográficas consolidadas. Em 1988, Sergio Miceli, na obra A elite eclesiástica brasileira, associou a descentralização operada pelo regime republicano, a montagem de partidos republicanos nos diversos estados brasileiros e a considerável autonomia das oligarquias ao processo de "estadualização" das políticas implementadas pelo episcopado brasileiro. Em decorrência, todas as capitais foram elevadas à condição de dioceses, a fim de realizar alianças com as facções oligárquicas estaduais e com o governo federal, com vistas a garantir um acúmulo patrimonial e apoio à política expansionista. Para o episcopado, teriam sido nomeados indivíduos que pertenciam às elites e que pudessem realizar alianças com as facções oligárquicas estaduais. ${ }^{6}$ Aquino teceu críticas a essa vertente interpretativa por ter "reduzido os esforços eclesiásticos à construção de um pacto oligárquico" e por desconsiderar os interesses institucionais. Assim, a criação de novas circunscrições eclesiásticas permitiram ampliar o controle religioso em todo o território nacional,

\footnotetext{
${ }^{3}$ MARIN, Jérri Roberto. A Santa Sé e a criação de novas circunscrições eclesiásticas em 1892. In Revista Brasileira de História das Religiões, Maringá, ano XIV, v. 14, n. 40, maio/ago., pp. 221-250, 2021.

${ }^{4}$ Consultar MARIN, Circunscrições eclesiásticas... op. cit.

${ }^{5}$ SANTIROCCHI, Ítalo Domingos. Uma questão de revisão de conceitos: romanização - ultramontanismo - reforma. In Temporalidades, Belo Horizonte, v. 2, n. 2, pp. 24-33, 2010; MARIN, Jérri Roberto. Reflexões sobre a imprensa católica no Brasil. In Religião e Sociedade, Rio de Janeiro, v. 38, n. 3, set./dez., pp. 197-217, 2018; DUTRA NETO, Luciano. Das terras baixas da Holanda às montanhas de Minas: uma contribuição à história das missões redentoristas, durante os primeiros trinta anos de trabalho em Minas Gerais. Tese (Doutorado em História) - Universidade Federal de Juiz de Fora, Juiz de Fora, 2006, pp. 30-31.
}

${ }^{6}$ MICELI, Sergio. A elite eclesiástica brasileira. Rio de Janeiro: Bertrand, 1988, p. 22. 
fortalecer a presença da Igreja Católica na sociedade, legitimar o poder do Estado e adequar-se "às necessidades sociopolíticas e religiosas específicas de cada unidade federativa".?

Outra perspectiva interpretativa questionada é a de que as iniciativas para criar novas dioceses e arquidioceses partiam da autoridade episcopal que, movida pelo zelo e alinhamento às diretrizes da Santa Sé, mobilizava as elites locais, a população e o representante pontifício. ${ }^{8}$ Isso poderia acontecer apenas com os bispos mais alinhados às diretrizes da Santa Sé, como D. Sebastião Leme, e que estavam preocupados com a eficácia da gestão das dioceses ${ }^{9}$, com a maior intervenção e inserção da Nunciatura Apostólica, e com a ampliação do diálogo e da cooperação do episcopado com os representantes pontifícios e com a Santa Sé, cujas relações estavam mais hierárquicas e centralizadoras. ${ }^{10}$

As divisões eclesiásticas foram, em sua maioria, processos que envolveram disputas e tensões entre o episcopado e a Santa Sé, que desejava acelerar os desmembramentos das dioceses e o episcopado que, por sua vez, resistia, retardando o avanço dessas reformas. Diante disso, os representantes pontifícios negociaram com os bispos, impunham a divisão por meio da submissão hierárquica ou recorriam a expedientes como a transferência do bispo e a imposição de renúncia. Dessa forma, é necessário analisar as políticas e as estratégias da Santa Sé, o papel dos secretários de Estado e dos representantes pontifícios e as singularidades do cenário religioso e de cada diocese, pois existiam divergências e embates quanto às reformas que deveriam ser realizadas.

\footnotetext{
${ }^{7}$ AQUINO, Mauricio de. Modernidade republicana e diocesanização do catolicismo no Brasil: a construção do bispado de Botucatu no sertão paulista (1989-1923). Tese (Doutorado em História) - Universidade Estadual Paulista, Assis, 2012, pp. 23, 25, 30, 82.

${ }^{8}$ De acordo com Manuel (2008, p. 58), em “todas as histórias de criação de dioceses ou paróquias, é possível identificar a mesma lógica: a autoridade eclesiástica propunha a criação e desenvolvia um trabalho junto às elites locais, a fim de angariar os recursos financeiros necessários à nova divisão eclesiástica". MANOEL, Ivan Aparecido. A criação de paróquias e dioceses no Brasil no contexto das reformas ultramontanas e da ação católica. In: SOUZA, Rogério Luiz de; OTTO, Clarícia (org.). Faces do catolicismo. Florianópolis: Insular, 2008, pp. 41-59.

${ }^{9}$ MOURA, Carlos André Silva de; CABRAL, Newton Darwin de Andrade. Reorganização eclesiástica em Pernambuco: o processo de formação das Dioceses de Garanhuns, Nazaré e Pesqueira (1910-1918). In Revista Brasileira de História das Religiões, Maringá, v. 13, n. 38, set./dez., pp. 145-163, 2020.
}

${ }^{10}$ MARIN, Reflexões sobre.... op. cit., p. 209. 


\section{Os olhares da Santa Sé sobre Mato Grosso e a gestão de D. Carlos Luiz D'Amour}

As imagens que os representantes pontifícios tinham acerca do Mato Grosso aproximavam-se daquelas ideias veiculadas na Europa sobre as regiões desconhecidas e isoladas e de clima tropical. Seria uma terra incógnita, isolada, remota, inexplorada, desconhecida, pouco povoada, habitada por indígenas pagãos e com grande extensão territorial. As distâncias eram definidas também pela ausência de aglomerações urbanas ou rurais. Situar-se "longe" ou "perto" queria dizer uma representação espacial que designava a proximidade ou distância com os signos de civilização, ou seja, demarcava diferenças culturais mais do que distâncias geográficas. No aspecto religioso, seria uma terra nullius, ou seja, sem dono, de ninguém, abandonada, de missão, ainda não ocupada pela Igreja Católica, onde era necessário ampliar a presença institucional. A escassez de clero e de recursos religiosos gerava os estigmas de atraso religioso, pois as populações estavam desassistidas. A presença de indígenas pagãos associava Mato Grosso às terras bárbaras e incivilizadas e à margem do progresso.

A Santa Sé acompanhava, com muito interesse, o cenário religioso da diocese de Cuiabá e a gestão de D. Carlos. Os instrumentos de controle eram variados, tais como relatórios, questionários, pedidos de esclarecimentos, prestações de contas e as visitas ad limina apostolorum a Roma a cada cinco anos. Outro meio de obtenção de informações eram as correspondências e os telegramas. Os representantes pontifícios solicitavam esclarecimentos e consultavam-no sobre determinados temas; além disso, trocavam inúmeras correspondências com vários bispos e pessoas consideradas confiáveis, a fim de conhecer o cenário religioso e de obter informações sobre D. Carlos. 0 objetivo era ter diferentes pontos de vista, corrigir possíveis erros interpretativos e, por fim, ter uma posição oficial, para formular propostas e soluções.

A vigilância dos representantes pontifícios sobre D. Carlos, e sobre todo o episcopado brasileiro, era articulada, produtiva, eficiente, subdividida e funcionava a todo instante, instaurando uma assimetria entre o que vigiava e o que era vigiado, permitindo apreender o indivíduo, saber o que ele era, o que fazia, como fazia, suas qualidades e defeitos, suas atitudes e comportamentos privados, o que se poderia fazer dele, ou onde seria preciso colocá-lo, como situá-lo entre os outros e como agir para controlá-lo. ${ }^{11}$ As possibilidades de privacidade, liberdade e autonomia como gestor diocesano existiam, mas eram

${ }^{11}$ FOUCAULT, Michel. Vigiar e punir: história da violência nas prisões. Petrópolis: Vozes, 1987. 
julgadas e tuteladas pelos fiéis, pelos padres, pelos colegas de episcopado, bem como pelo papa e pela Cúria Romana.

D. Carlos tornou-se objeto de permanente análise, reflexão, organização, classificação, avaliação, hierarquização, julgamento, que autorizavam as gratificações ou as sanções normalizadoras, ao marcarem suas qualidades, méritos, aptidões, desvios e defeitos etc. Ou seja, a permanente intrusão era um instrumento de controle, tutelando sua privacidade, sua liberdade como autoridade eclesiástica, sua gestão episcopal e criando estratégias para intervenção, que poderiam ser para promover ou para punir, censurar, discriminar, impelir à ação, obrigando-o a submeter-se e até para obter sua transferência (punitiva ou promocional) ou sua renúncia. Como bispo e membro da hierarquia eclesiástica, deveria cumprir inúmeras obrigações e exigências sociais, ao agir, mover-se, pensar e administrar a diocese, e a expectativa era de que sua gestão fosse produtiva, eficiente, alinhada à Santa Sé, empreendedora, que implantasse as reformas internas e que desmembrasse o território diocesano.

O vigiado não tinha conhecimento de que estava sendo observado, embora soubesse que poderia sê-lo. Para tornar a vigilância indecidível e funcionando em silêncio, recorria-se aos rigorosos compromissos do "segredo pontifício" e do "segredo absoluto". No campo de forças, o bispo devia obediência aos superiores hierárquicos, tais como representantes pontifícios, à Cúria Romana e ao papa. Nesse campo de lutas, os atores, conforme sua posição na estrutura de relações sociais, relacionavam-se, enfrentavam-se, resistiam e trocavam de posição a cada momento.

Porém, obter informações acerca das terras mato-grossenses e sobre D. Carlos não era tarefa fácil, pelas dificuldades nas comunicações. O serviço de correio não era regular, havia extravio de malotes e poderia levar vários meses. A construção da linha telegráfica, em 1891, permitiu conectar a região às redes nacionais e internacionais e agilizar as comunicações, mas havia interrupções no funcionamento da rede, por queda de postes e fios, assim como extravio e divulgação dos conteúdos dos telegramas. Por essas razões, os serviços postais e telegráficos de Mato Grosso eram considerados os piores do Brasil. ${ }^{12}$

D. Carlos, pela escassez de recursos e pelas distâncias geográficas, permaneceu isolado e raramente participou das reuniões episcopais. Ele alegava também problemas de saúde e escassez de recursos, que o impossibilitavam

${ }^{12}$ BNDigital (Biblioteca Nacional Digital - Hemeroteca Digital), o Correio. 0 Commercio, Cuiabá, ano I, n. 16: 2, 16 jun. 1910. 
de realizar viagens. A viagem de navio a vapor de Cuiabá ao Rio de Janeiro tinha duração de 40 dias. Durante os 43 anos de episcopado, realizou apenas duas visitas ad limina apostolorum a Roma, em 1889 e 1906, que eram obrigatórias e deveriam ser realizadas a cada cinco anos. Esse problema não era enfrentado apenas por D. Carlos, mas pela maioria dos bispos. Em 1899, por exemplo, houve pressões para que o episcopado brasileiro participasse do Concílio Plenário Latino-Americano, que seria realizado em Roma. D. Joaquim Arcoverde de Albuquerque Cavalcanti, arcebispo do Rio de Janeiro, informou Henrique Sibilia sobre as distâncias geográficas entre as dioceses do Brasil e destas com relação à Europa, pois em "Roma não teriam uma ideia precisa". ${ }^{13}$ D. Carlos justificava suas ausências pelo estado de saúde, pela escassez de recursos e pelas distâncias geográficas.

o Código de Direito Canônico relacionava o território diocesano ao bispo, assim como sua atuação, habilidades e posturas definiam a diocese a ele confiada. A trajetória de D. Carlos foi marcada por inúmeras controvérsias e conflitos, que o colocavam sob permanente suspeição. Para os núncios apostólicos, era um bispo do império, estigma que hierarquizava o episcopado, tendo como referência temporal a instalação do regime republicano, e eles distinguiam-no pela má-formação intelectual, pelas posturas independentes em relação à Santa Sé, por ser pouco zeloso e empreendedor e por não desejar desmembrar o território de suas dioceses. D. Carlos seria um "pobre bispo", que administrava uma vasta e "infeliz diocese". Para D. Arcoverde, o núncio Giulio Tonti (1902-1906) deveria ser seu "anjo protetor", pois ele vivia "muito abandonado" e precisava ser auxiliado para reorganizar a diocese. ${ }^{14}$

Em 1882, o internúncio Mario Mocenni (1882) procurou obter informações acerca da diocese de Cuiabá e da gestão de D. Carlos. Aproveitando a estada de um missionário capuchinho, que tinha viajado a Mato Grosso e encontrava-se no Rio de Janeiro, intimou-o para uma reunião. As informações que foram repassadas eram de que a diocese de Cuiabá tinha grande extensão territorial, clero escasso, população diminuta ${ }^{15}$ e que estava desassistida por

\footnotetext{
${ }^{13}$ Archivio Apostolico Vaticano (A.A.V.), Indici 1153, Fondo della Nunziatura Apostolica in Brasile (A.N.B.), Busta 93, Fascicolo 456. Carta de D. Joaquim Arcoverde de Albuquerque Cavalcanti para Henrique Sibilia, 28 maio 1899.

${ }^{14}$ A.A.V., Indici 1153, A.N.B., Busta 101, Fascicolo 496. Carta de D. Joaquim Arcoverde de Albuquerque Cavalcanti para Giulio Tonti, 22 mar. 1904.

${ }^{15}$ As informações repassadas eram de que a população de Mato Grosso estava entre 34 mil e 35 mil habitantes, excluindo as populações indígenas, e a de Cuiabá, entre 3 mil e 4 mil habitantes. Ou seja, as informações eram imprecisas, pois o Censo de 1872 contabilizou que a população era de 35.987 habitantes em Cuiabá e 60.417 em Mato Grosso. Já o Censo de 1890 demonstrou que a população de Cuiabá era de 27.093
} 
falta de padres, e com centenas de indígenas não cristianizados. Os mato-grossenses teriam boa índole, sendo "tranquilos e pacíficos, porém ignorantes nos assuntos religiosos devido à escassez de clero". Sobre o clero, informou que os nove padres seculares seriam negligentes e "concubinos, sem exceção", e apenas três do clero regular seriam "bons". Das 16 paróquias existentes, oito estavam vacantes, e a diocese não tinha seminário diocesano e capítulo catedrático. D. Carlos teria uma moral ilibada e seria "educado e zeloso", porém muito austero, e, por isso, indispunha-se frequentemente com o clero e os fiéis. As informações obtidas foram repassadas a Luigi Jacobini, secretário de Estado, e ao papa Leão XIII, que exprimiu sua tristeza diante "do estado deplorável da vastíssima diocese” de Cuiabá. O internúncio foi aconselhado a endossar o pedido à Congregação Salesiana para que atuasse em Mato Grosso, a fim de melhorar a assistência religiosa à população e aos indígenas. ${ }^{16}$

Em 1893, estava sendo debatido o provimento da arquidiocese da Bahia, vacante desde o falecimento de D. Antônio de Macedo Costa, em 20 de março de 1891. O ministro das Relações Exteriores, juntamente com outros dois ministros, procurou o internúncio Girolamo Maria Gotti (1892-1895) para indicar D. Carlos ao referido cargo. Eles alegaram que ele conhecia os problemas da arquidiocese, que tinha prestígio entre as autoridades estaduais e federais e que era estimado pelos baianos, sobretudo por sua atuação como vigário capitular e administrador diocesano. 0 internúncio resguardou-se na separação entre Igreja e Estado, para indeferir o pedido, e alegou, respaldado em informantes considerados confiáveis, que D. Carlos não era estimado pelo episcopado brasileiro e pelo clero de Mato Grosso. Também considerou que não se distinguia pela ciência, por sua administração, nem pelo caráter, modos e personalidade. ${ }^{17}$

As relações de D. Carlos com o clero regular foram marcadas por inúmeros conflitos. Em 1888, passaram a atuar na diocese os lazaristas e as irmãs de São Vicente de Paulo. Os lazaristas dirigiram o seminário diocesano, porém as sucessivas intervenções e ingerências do bispo nos assuntos internos geraram tensões e desentendimentos. O impasse terminou com o afastamento dos

\footnotetext{
habitantes, e a de Mato Grosso, de 92.827. BUENO, Francisco Antonio Pimenta. Memória justificativa dos trabalhos que foi encarregada a província de Mato Grosso segundo as instruções do Ministério da Agricultura, de 27 de março de 1879. Rio de Janeiro: Nacional, 1880, p. 75.

${ }^{16}$ A.A.V., Segretaria di Stato, anno 1882, rubrica 251, fasc. 3. Carta de Mario Mocenni para Luigi Jacobini, 8 ago. 1882; Carta de Luigi Jacobini para Mario Mocenni, 13 set. 1882 (tradução nossa).

${ }^{17}$ Segreteria di Stato (S.S.), Sezione per i Rapporti con gli Stati (S.RR.SS.), Archivio Storico (A.S.), Congregazione degli Affari Ecclesiastici Straordinari (AA.EE.SS.), Brasile II, Anno 1892-1893, Pos. 350, Fascicolo 40, n. 350. Carta de Girolamo Maria Gotti para Mariano Rampolla del Tindaro, 14 abr. 1893.
} 
lazaristas e o fim da missão em Mato Grosso, em 1894. D. Carlos considerava-os incompetentes e fracassados, qualificando de ingloriosa sua atuação em Mato Grosso. As irmãs de São Vicente de Paulo, que administravam o asilo Santa Rita, também se retiraram em razão das constantes intervenções episcopais, da falta de um confessor e do isolamento geográfico.

Em junho de 1894, passaram a atuar em Mato Grosso os salesianos e, em 1895, as irmãs Filhas de Maria Auxiliadora. Desde a chegada, suas relações com D. Carlos foram marcadas por tensões e enfrentamentos. Em 1902, ele desejou conhecer o Livro dos Privilégios, conferidos pela Santa Sé, pois era cioso de seus direitos e prerrogativas hierárquicas. O confronto mais grave ocorreu em 1903, por ocasião das intervenções para reformar a festa do Espírito Santo na catedral de Cuiabá, a mais popular e que arrecadava muitas doações. Alguns padres salesianos não cumpriram as portarias e determinações que proibiam a celebração de missa festiva em todas as igrejas e capelas da diocese. 0 impasse entre os salesianos e o bispo deveu-se a uma missa encomendada pelo festeiro. O padre Helvécio Gomes de Oliveira entendeu ser inexistente a proibição de missa campal e celebrou-a, de forma festiva, no pátio do Liceu Salesiano. Como reação à desobediência, D. Carlos suspendeu os padres salesianos de todas as faculdades outorgadas, com exceção daquelas das capelas dos colégios, e eles foram exonerados da administração das paróquias de São Gonçalo e de Santo Antônio. Após, foram publicadas novas portarias, limitando a celebração de missas votivas e pelos finados nas capelas dos colégios. Os salesianos, diante das sanções, ameaçaram retirar-se da diocese e as irmãs Filhas de Maria Auxiliadora entregaram a administração do asilo Santa Rita, fundado por D. Carlos. O núncio e o arcebispo Arcoverde intermediaram as negociações, para acalmar os ânimos. Para solucionar o impasse, os salesianos tiveram de aceitar duas condições impostas pelo núncio apostólico: a transferência do padre Helvécio de Mato Grosso e um documento de Antônio Malan, que era o superior da missão salesiana, no qual reprovava as atitudes de Helvécio, declinando de qualquer conivência com elas.

Esses incidentes despertaram novo interesse da Santa Sé sobre a gestão de D. Carlos, sobre o que ele pensava, como agia e comportava-se, e sobre sua conduta privada e sexual. Em 1904, o secretário de Estado Raffaele Merry del Val, para obter informações mais precisas, convocou para uma reunião um religioso "digno de confiança" e que tinha viajado recentemente a Mato Grosso. As informações foram consideradas "sérias" e "dolorosas", entre elas que havia grande escassez de clero, especialmente na cidade episcopal, que era atendida por cinco padres seculares, todos idosos e com uma 
vida pública "escandalosa"; que o seminário diocesano estaria abandonado, podendo ser considerado inexistente; e que havia discórdias entre o bispo e os salesianos, motivadas por vinganças e ressentimentos. D. Carlos seria um bispo negligente, inerte, e sua gestão episcopal era desastrosa. $\mathrm{O}$ informante denunciou D. Carlos por assédio sexual às irmãs Filhas de Maria Auxiliadora, não respeitando sua "idade", e o "caráter religioso e episcopal". Ao tomar conhecimento, Merry del Val solicitou que o núncio Giulio Tonti (1902-1906) apurasse a veracidade dessas graves denúncias e, caso fossem comprovadas, obtivesse a renúncia do bispo. ${ }^{18}$

Tonti, sem mencionar as acusações, solicitou de D. Carlos uma prestação de contas de sua administração e, de forma sigilosa, procurou obter informações mais precisas sobre sua conduta privada, com pessoas consideradas confiáveis. ${ }^{19}$ As conclusões foram de que as condições da diocese eram ruins, em razão da grande extensão territorial, das dificuldades nas comunicações, do pequeno número de paróquias, da escassez de recursos e de clero, bem como pelo fato de o seminário não estar sob boa administração e em virtude de a população, em sua maioria, estar sem assistência religiosa. A gestão de D. Carlos foi considerada "péssima", como defendiam os informantes da Santa Sé, pelas "circunstâncias excepcionais da diocese". Entre os defeitos do bispo estariam a idade avançada, ser cioso de sua posição hierárquica, ter posturas xenófobas em relação ao clero estrangeiro e uma personalidade austera e irascível, que era considerada uma característica nata dos brasileiros e presente em todos os membros do episcopado brasileiro..$^{20}$ Tonti posicionou-se favorável aos salesianos e minimizou o ocorrido, qualificando-o apenas como "imprudência" do padre Helvécio. ${ }^{21}$ Quanto à denúncia de assédio, D. Arcoverde foi consultado e considerou-a caluniosa, por ser de "origem salesiana", pois os salesianos seriam "inimigos do Snr. Bispo", tendo sido motivadas pelas reformas que ele tentou implantar na diocese. Ele esclareceu que D. Carlos tinha 67 anos e que nunca ouvira falar nada que depusesse sobre sua conduta privada. Por fim, considerou-o um "martyr do isolamento", sem que tivesse pessoas de confiança para consultar em suas dúvidas e hesitações. Quanto

\footnotetext{
${ }^{18}$ A.A.V., Indici 1153, A.N.B., Busta 101, Fascicolo 496. Carta de Raffaele Merry del Val para Giulio Tonti, 2 maio 1904 (tradução nossa).

${ }^{19}$ A.A.V., Indici 1153, A.N.B., Busta 101, Fascicolo 496. Carta de Giulio Tonti para Raffaele Merry del Val, 30 ago. 1904; Carta de D. Carlos Luiz D’Amour para Giulio Tonti, 28 jun. 1903.

${ }^{20}$ S.S., S.RR.SS., A.S., AA.EE.SS., Brasile III, Anno 1904-1905, Pos. 643-645. Fascicolo 122. Carta de Giulio Tonti para Raffaele Merry del Val, 30 ago. 1904.

${ }^{21}$ S.S., S.RR.SS., A.S., AA.EE.SS., Brasile III, Anno 1904-1905, Pos. 643-645. Fascicolo 122. Carta de Giulio Tonti para Raffaele Merry del Val, 30 ago. 1904 (tradução nossa).
} 
à punição aos salesianos, considerou-as "severas" e próprias de um bispo, e não de um missionário. ${ }^{22}$

Para o núncio, os problemas da diocese de Cuiabá eram os mesmos que os demais bispados enfrentavam, porém agravados pela extensão territorial, pelas distâncias geográficas, pelas dificuldades nas vias de comunicação, pela escassez de clero e pelo estilo de mando de D. Carlos. Para Tonti, o único meio para melhorar esse cenário "deplorável" e "pouco florido" era impor, com urgência, um bispo auxiliar para que o ajudasse no governo da "vasta e difícil" diocese e promovesse melhorias nas condições "excepcionalmente espinhosas". ${ }^{23} \mathrm{O}$ representante pontifício recebeu instruções precisas para agir de forma diplomática, a fim de não ferir as suscetibilidades do bispo e criar novos incidentes, pois era considerado de temperamento austero. Entre as preocupações estavam a de não transparecer que seria uma imposição ou obrigatoriedade e a de que a Santa Sé considerava deploráveis as condições da diocese. Ou seja, as iniciativas do núncio deveriam ser cautelosas, porém firmes, para impor as mudanças necessárias. ${ }^{24}$

D. Carlos, submetendo-se aos conselhos do núncio e de D. Arcoverde, solicitou a nomeação de um bispo auxiliar, com direito à sucessão, alegando sua idade avançada (67 anos) e problemas de saúde. A decisão foi comemorada pelo núncio, pois considerava-o "egoísta" e avarento por "querer desfrutar sozinho das rendas da diocese". ${ }^{25}$ Para D. Arcoverde, a nomeação seria uma alavanca para impulsionar a reestruturação da "infeliz diocese". ${ }^{26} \mathrm{O}$ papa Pio $\mathrm{X}$ considerou a designação oportuna diante da "conduta" de D. Carlos e do cenário religioso da diocese ${ }^{27}$ Houve o empenho do núncio e de Arcoverde em conseguir que ordens ou congregações religiosas aceitassem fundar casas em Mato Grosso e em conseguir um candidato apto a bispo auxiliar. ${ }^{28}$ Como resul-

\footnotetext{
${ }^{22}$ A.A.V., Indici 1153, A.N.B., Busta 101, Fascicolo 496. Carta de D. Joaquim Arcoverde de Albuquerque Cavalcanti para Giulio Tonti, 21 out. 1904.

${ }^{23}$ S.S., S.RR.SS., A.S., AA.EE.SS., Brasile III, Anno 1904-1905, Pos. 643-645. Fascicolo 122. Carta de Giulio Tonti para Raffaele Merry del Val, 30 ago. 1904; Carta de Giulio Tonti para Raffaele Merry del Val, 25 out. 1904.

${ }^{24}$ A.A.V., Indici 1153, Segreteria di Stato, Anno 1910, Rúbrica 251, fascículo 25. Carta de Raffaele Merry del Val para Alessandro Bavona, 28 set. 1910; A.A.V., Indici 1153, A.N.B., Busta 132, Fascicolo 153. Carta de Raffaele Merry del Val para Alexandre Bavona, 30 set. 1910.

${ }^{25}$ S.S., S.RR.SS., A.S., AA.EE.SS., Brasile III, Anno 1904-1905, Pos. 643-645. Fascicolo 122. Carta de Raffaele Merry del Val para Giulio Tonti, 24 maio 1904 (tradução nossa).

${ }^{26}$ A.A.V., Indici 1153, A.N.B., Busta 101, Fascicolo 496. Carta de D. Joaquim Arcoverde de Albuquerque Cavalcanti para Giulio Tonti, 22 mar. 1904 (tradução nossa).

${ }^{27}$ A.A.V., Indici 1153, A.N.B., Busta 101, Fascicolo 496. Carta de Raffaele Merry del Val para Giulio Tonti, 10 out. 1903; Carta de D. Joaquim Arcoverde de Albuquerque Cavalcanti para Giulio Tonti, 4 dez. 1904.

${ }^{28}$ A.A.V., Indici 1153, A.N.B., Busta 101, Fascicolo 496. Carta de D. Carlos Luiz D’Amour para Giulio Tonti, 24 nov. 1905.
} 
tado desses esforços, estabeleceram-se na diocese os franciscanos da Ordem Terceira Regular, em 1904, e as irmãs da Imaculada Conceição de Castres, em 1906. O seminário diocesano foi confiado à Terceira Ordem Regular de São Francisco, e, para evitar as intervenções de D. Carlos, o regulamento foi reformulado, permitindo maior autonomia.

O processo para a nomeação do bispo auxiliar é revelador das dificuldades para conseguir candidatos aptos entre o clero, sobretudo laboriosos, com boa formação intelectual, com conduta moral ilibada e capacidades administrativas e de liderança. Outro problema era que aceitassem assumir esse posto em Mato Grosso. Inicialmente, a nunciatura acolheu a sugestão de D. Carlos de que fosse indicado o padre Diego de Amorim Freitas. Porém, ele não aceitou, alegando problemas de saúde, incapacidade intelectual, ser despossuído de dotes administrativos e por ser uma missão árdua e delicada demais..$^{29} \mathrm{O}$ arcebispo Arcoverde indicou o padre João Batista Porto, que não aceitou, alegando problemas de saúde e incapacidade para ser elevado à dignidade episcopal, deixando-o muito contrariado. O núncio, por sua vez, reclamou do "longo e penoso trabalho" para escolher os candidatos ao episcopado, que poderia levar meses e anos, pelas dificuldades nas comunicações e pelo "caráter brasileiro", ou seja, por suas "inconstâncias", negatividades atribuídas às questões raciais e à mestiçagem..$^{30}$ Posteriormente, foi indicado o padre Cirilo de Paula Freitas, que, apesar de não ter a formação acadêmica exigida, foi considerado ativo, trabalhador, zeloso e cumpridor de seus deveres sacerdotais. ${ }^{31}$ Em 8 de setembro de 1904, D. Carlos solicitou que o papa Pio X nomeasse-o bispo auxiliar, com direito à sucessão, apresentando-o como apto para o "elevado e difícil cargo".32

Pio X aprovou a indicação do padre Cirilo e, para reforçar sua autoridade e poder, solicitou que sua sagração fosse realizada em Roma, com o intuito de presidir o ritual. Esse exercício do poder papal tinha por finalidade reduzir D. Carlos à impotência total e a adversário, transformando o futuro bispo auxiliar

\footnotetext{
${ }^{29}$ A.A.V., Indici 1153, A.N.B., Busta 101, Fascicolo 496. Carta de Raffaele Merry del Val para Giulio Tonti, 10 out. 1903; Carta de D. Carlos Luiz D’Amour para Giulio Tonti, 8 set. 1904; Carta de Giulio Tonti para Raffaele Merry del Val, 3 out. 1903; Carta de Diego de Amorim Freitas para Giulio Tonti, 29 set. 1902.

${ }^{30}$ S.S., S.RR.SS., A.S., AA.EE.SS., Brasile II, Anno 1902-1903, Pos. 608-616, Fascicolo 109, N. 609. Carta de João Batista Porto a Joaquim Arcoverde de Albuquerque Cavalcanti, 31 maio 1904; Carta de Giulio Tonti para Raffaele Merry del Val, 15 fev. 1904 (tradução nossa).

${ }^{31}$ A.A.V., Indici 1153, A.N.B., Busta 101, Fascicolo 496. Carta do Carta de D. Joaquim Arcoverde de Albuquerque Cavalcanti para Giulio Tonti, 21 out. 1904.

${ }^{32}$ S.S., S.RR.SS., A.S., AA.EE.SS., Brasile III, Anno 1904-1905, Pos. 643-645. Fascicolo 122. Carta de D. Carlos Luiz D'Amour para Pio X, 4 set. 1904.
} 
em escolhido. ${ }^{33}$ Porém, o padre Cirilo não teve condições econômicas para pagar as taxas das bulas, nem para viajar a Roma. Os bispos de Diamantina e Cuiabá, em razão da escassez de rendas, afirmaram que não podiam auxiliá-lo nas despesas. Os valores que D. Carlos enviou para pagar os custos da sagração episcopal foram considerados "de uma pobreza que [excedia] a expectativa". ${ }^{4}$ Para contornar a situação, Pio X reduziu as despesas da expedição da bula em 50\%. ${ }^{35} \mathrm{Em} 27$ de março de 1905, D. Cirilo foi nomeado bispo auxiliar, e sua sagração ocorreu em 7 de janeiro de 1906. Em 12 de agosto de 1906 , tomou posse, permitindo que D. Carlos realizasse sua segunda visita ad limina apostolorum a Roma. ${ }^{36}$

\section{A gestão do núncio Alessandro Bavona}

Em 1907, foi nomeado o núncio apostólico Alessandro Bavona, que ocupou o cargo até 1911. A escolha deveu-se à sua capacidade diplomática e de articulação, além de ser um indivíduo dinâmico, ativo e carismático. Suas intervenções e articulações favoreceram a maior inserção da Santa Sé no Brasil, ampliando o diálogo e a cooperação com o episcopado. Ao longo de sua gestão, conquistou grande prestígio no meio governamental e exerceu uma liderança forte e eficaz sobre o episcopado, a fim de promover a aproximação com o Estado, multiplicar as circunscrições eclesiásticas, defender os interesses católicos e promover a cristianização da sociedade.

Em 1906, o Brasil tinha 21 circunscrições eclesiásticas, sendo quatro arquidioceses, 16 dioceses e uma prelazia. Dessas, nove foram criadas durante o regime republicano. Esses números eram considerados insuficientes, ao se considerar a superfície territorial do país, a grande extensão das dioceses, as dificuldades nas vias de comunicação e nos censos populacionais. As instruções do secretário de Estado, Raffaele Merry Del Val, recomendavam que Bavona se empenhasse para expandir as circunscrições eclesiásticas. ${ }^{37}$

\footnotetext{
${ }^{33}$ A.A.V., Indici 1153, A.N.B., Busta 101, Fascicolo 496. Carta de Raffaele Merry del Val para Giulio Tonti, 10 out. 1903.

${ }^{34}$ A.A.V., Indici 1153, A.N.B., Busta 101, Fascicolo 496. Carta de Joaquim Arcoverde de Albuquerque Cavalcanti para Giulio Tonti, 21 fev. 1905.

${ }^{35}$ S.S., S.RR.SS., A.S., AA.EE.SS., Brasile III, Anno 1904-1905, Pos. 643-645. Fascicolo 122. Telegrama de Raffaele Merry del Val para Giulio Tonti, 5 jun. 1905.

${ }^{36}$ A.A.V., Indici 1153, A.N.B., Busta 101, Fascicolo 496. Carta de D. Carlos Luiz D’Amour para Giulio Tonti, 24 nov. 1905.

${ }^{37}$ A.A.V., Indici 1153, A.N.B., Busta 118, Fascicolo 581. Instruzioni per Monsig. Alessandro Bavona, Arcivescovo di Tarsaglia, Nunzio Apostolico in Brasile, 1907.
} 
Para Bavona, era inadmissível que as dioceses brasileiras tivessem territórios equivalentes a países como a França, a Itália e a Alemanha. Ao comparar o Brasil aos Estados Unidos, México e Canadá, observou a menor quantidade de circunscrições eclesiásticas em proporção à sua extensão territorial e quantidade de católicos. Esse descompasso foi atribuído às heranças do regalismo imperial e às resistências do episcopado, que relutava em dividir suas dioceses, preferindo-as com grandes extensões territoriais. Tal postura era vista como contrária à missão episcopal, que deveria estar empenhada no incremento religioso. Como decorrência, havia lentidão nos desmembramentos das dioceses e sua distribuição espacial era desigual, ou seja, era maior no centro-sul, sendo necessário incrementá-las em todas as regiões. ${ }^{38}$

A estratégia da Santa Sé era elevar o número de dioceses e províncias eclesiásticas, para melhorar a gestão episcopal, acelerar as reformas e promover ações conjuntas do episcopado. Desde 1905, foram elaborados inúmeros estudos sobre o Brasil, em que foram analisadas as relações entre superfície territorial e população das duas províncias eclesiásticas, a partir dos dados fornecidos pelo Censo de 1890 e dos cálculos de Toledo Pizza, que apresentava dados divergentes dos oficiais, sendo considerados mais confiáveis. ${ }^{39}$ Esses dados estatísticos forneceram subsídios para os projetos de criação de novas circunscrições eclesiásticas e evidenciavam que o Brasil era objeto permanente de observação, reflexão, estudos e análises, que estabeleceram uma autoridade científica e religiosa da Santa Sé sobre o Brasil. Também forneceram elementos que instituíram e consagraram distinções e divisões territoriais, geográficas, culturais, econômicas, populacionais e religiosas, que legitimaram projetos distintos para ordenar o território brasileiro, no sentido administrativo e político e de gestão das populações. O objetivo era desmembrar as dioceses extensas e as que tinham maior ou menor densidade demográfica, bem como ampliar o número de arquidioceses. Bavona pretendia criar oito províncias eclesiásticas, 38 dioceses, duas prelazias, duas prefeituras apostólicas e elevar o episcopado a 43 membros. ${ }^{40}$

\footnotetext{
${ }^{38}$ S.S., S.RR.SS., A.S., AA.EE.SS., Brasile III, Anno 1907-1908, Pos. 701-702, Fascicolo 141. Carta de Alessandro Bavona para Raffaele Merry del Val, 21 jan. 1908.

${ }^{39}$ A.A.V., Indici 1153, A.N.B., Busta 99, Fascicolo 486, Quadro das Archidioceses e Dioceses do Brasil, com a superficie, a população segundo o recenceamento oficial de 1890 e a actual segundo o calculo do Dr. Toledo Pizza, geralmente consentido e adaptado.

${ }^{40}$ S.S., S.RR.SS., A.S., AA.EE.SS., Brasile III, Anno 1911, Rubrica 251, Fascicolo 4. Carta de Alessandro Bavona para Raffaele Merry del Val, 22 jan. 1910.
} 


\section{A criação da província eclesiástica de Cuiabá}

A província eclesiástica do Rio de Janeiro teria uma superfície de 2.893.123 km² e uma população de 7.597.916 habitantes, segundo o recenseamento de 1890 , e de 11.301 .800 , segundo o cálculo do Dr. Toledo Pizza. A diocese de Cuiabá tinha a maior superfície de toda a província eclesiástica do Rio de Janeiro, com $1.374 .651 \mathrm{~km}^{2}$, e perdia apenas para a diocese do Amazonas (1.897.020) e do Pará (1.149.712), que pertenciam à província eclesiástica de Salvador. Quanto à população, era a menos populosa do Brasil, tendo, em 1890, 92.827 habitantes e, em 1904, 157 mil habitantes. Como decorrência, tinha também a menor densidade demográfica $(8.787,58)$, seguida do Amazonas $(7.934,25)$, de Goiás $(2.197,97)$ e do Pará $(1.762,28) .{ }^{41}$

Para a Santa Sé, esses dados comprovavam a necessidade de dividir a diocese de Cuiabá, pois a grande extensão territorial, a rarefação demográfica, a escassez de clero e de recursos e as distâncias geográficas dificultavam sua gestão administrativa e a implantação das reformas institucionais. Era atribuição dos bispos propor a divisão de suas dioceses, e, como muitos resistiam, por temerem a perda das paróquias mais populosas, os desmembramentos não ocorriam no ritmo desejado pela Santa Sé. Nesse caso, cabia aos representantes pontifícios no Brasil e a D. Arcoverde, arcebispo do Rio de Janeiro, pressioná-los de forma cautelosa, a fim de evitar incidentes diplomáticos entre o episcopado e a Santa Sé. Sobre D. Carlos, como foi afirmado, pesava a imagem negativa de ser um "bispo do império", de "antiga escola", que não desejava dividir sua diocese. Além disso, era visto como mau administrador, sem capacidade de liderança e com má-formação intelectual. ${ }^{42}$

Bavona, desde sua posse, conseguiu articular, em 1908, a criação da província eclesiástica de São Paulo e estava negociando a criação de novas dioceses e das arquidioceses de Porto Alegre e Olinda. Planejou também desmembrar a diocese de Cuiabá. A estratégia utilizada para convencer D. Carlos foi agendar uma reunião. Ele aproveitou a estada de D. Carlos no Rio de Janeiro, após seu retorno da visita ad limina apostolorum a Roma, para participar da última sessão da V Conferência Episcopal da Província Meridional do Brasil. Nesse encontro, submetendo-se hierarquicamente à Santa Sé, D. Carlos concordou em desmembrar a diocese de Cuiabá, a fim de prover a assistência a

\footnotetext{
${ }^{41}$ A.A.V., Indici 1153, A.N.B., Busta 99, Fascicolo 486, Quadro das Archidioceses e Dioceses do Brasil, com a superficie, a população segundo o recenceamento oficial de 1890 e a actual segundo o calculo do Dr. Toledo Pizza, geralmente consentido e adaptado.

${ }^{42}$ A.A.V., Indici 1153, A.N.B., Busta 132, Fascicolo 153, Carta de Raffaele Merry Del Val para Alexandre Bavona, 6 ago. 1910 (tradução nossa).
} 
“tantas almas abandonadas”, criando duas dioceses ou vicariatos em Corumbá e em outra cidade do "interior". A primeira seria administrada por D. Cirilo de Paula Freitas, que seria transferido, e a segunda, entregue à Congregação Salesiana, que "seriam sustentados pelo governo" com o fim de "civilizar os indígenas". ${ }^{43}$

D. Carlos, ao retornar a Cuiabá, telegrafou, em 4 de junho de 1908, para comunicar que havia definido que seriam duas dioceses, e como sedes episcopais as cidades de Corumbá e Cáceres. A tarefa foi considerada “difícil”, porém "utilíssima". ${ }^{44}$ A tática de Bavona, para evitar que a iniciativa não prosperasse, foi a de "insistir" e de pressionar D. Carlos, porque era "a única maneira de evangelizar essas pessoas", de incrementar a presença da Igreja Católica na sociedade e de aumentar a hierarquia eclesiástica na região. ${ }^{45} \mathrm{D}$. Carlos nomeou duas comissões, a fim de prover os fundos necessários à manutenção dos futuros bispos, à aquisição de uma casa para sua residência e de reunir um patrimônio inicial. A comissão de Cáceres deveria também concluir a igreja, que seria elevada a catedral. Essas eram formadas por políticos e autoridades, inclusive pelo governador de Mato Grosso. A comissão de Corumbá era constituída pelo "Coronel Generoso Ponce, Presidente do Estado, Coronel Antonio Pedro Alves de Barros, ex-Presidente do Estado e Desembargador Terencio Vellozo", e a de São Luiz de Cáceres, composta por "Dr. Joaquim Augusto da Costa Marquez e Coronéis José Dulce e João Ferreira Mendes". ${ }^{46}$ Raffaele Merry del Val, em caráter de urgência, deu aval à proposta, considerando-a oportuna e premente. ${ }^{47}$

As cidades portuárias de Corumbá e São Luiz de Cáceres, além da capital, figuravam entre as mais importantes de Mato Grosso. Corumbá, por causa do porto fluvial, tornou-se importante empório comercial, com várias casas de importação e exportação e consulados. Era também centro de comunicação, por meio dos vários rios tributários, que a interligavam com o exterior, com as demais regiões do Brasil e com outras cidades de Mato Grosso. Era a

\footnotetext{
${ }^{43}$ A.A.V., Indici 1153, A.N.B., Busta 125, Fascicolo 619. Carta de Alessandro Bavona para Raffaele Merry del Val, 12 maio 1909 (tradução nossa).

${ }^{44}$ A.A.V., Indici 1153, A.N.B., Busta 122, Fascicolo 601. Carta de D. Carlos Luiz D’Amour para Alessandro Bavona, 4 jun. 1908 (tradução nossa).

${ }^{45}$ A.A.V., Indici 1153, A.N.B., Busta 125, Fascicolo 619. Carta de Alessandro Bavona, núncio apotólico, para Raffaele Merry del Val, 12 maio 1909 (tradução nossa).

${ }^{46}$ A.A.V., Indici 1153, A.N.B., Busta 122, Fascicolo 601. Carta de D. Carlos Luiz D’Amour ao núncio Alessandro Bavona, 4 jun. 1908.

${ }^{47}$ A.A.V., Indici 1153, A.N.B., Busta 125, Fascicolo 619. Carta de Raffaele Merry del Val para Alessandro Bavona, 16 jun. 1909.
} 
segunda cidade em densidade demográfica, com muitos imigrantes estrangeiros, sendo considerada a mais progressista de Mato Grosso. Cáceres era um centro comercial, com casas de importação e exportação e importantes fazendas dedicadas à criação de gado e à agricultura. D. Carlos considerou o grande desenvolvimento econômico que a estrada de ferro Noroeste do Brasil traria a Mato Grosso, cuja meta era atingir Campo Grande, em 1908, e Porto Esperança, em 1914. Havia a expectativa de que, no futuro, haveria grande progresso econômico e incremento demográfico. Apesar disso, Mato Grosso continuava a ser um estado com baixa densidade demográfica e com poucas cidades, distantes centenas de quilômetros umas das outras.

A notícia da divisão da diocese não agradou os positivistas, maçons e liberais, que eram anticlericais e participavam da Liga Mato-Grossense de LivrePensadores..$^{48}$ Eles criticavam a intolerância e o autoritarismo de D. Carlos, por ter acabado com a magnitude e o brilhantismo das festas religiosas e por fechar o seminário episcopal. Outra medida impopular seria a criação de dois novos bispados. Com isso, a gestão de D. Carlos estaria contribuindo para ofuscar a importância política e cultural de Cuiabá enquanto capital de Mato Grosso ${ }^{49}$ :

O que tem lucrado o Estado de Matto-Grosso, ou mais isoladamente, a sua capital, com a sede do unico bispado que ora possue, e principalmente depois que o governo desse bispado passou as mãos de S. Ex $x^{\mathrm{a}}$ ?

Que o digam aquelles que se recordam da época florescente do antigo seminário episcopal, há trinta ou quarenta annos, quando ali se ministrava a instrucção á mocidade.

\footnotetext{
${ }^{48}$ Denominavam-se Livre-Pensadores os estudantes e intelectuais da elite cuiabana que eram anticlericais, positivistas, evolucionistas e defendiam a laicidade do Estado e a secularização da sociedade. Em 1909, eles fundaram a Liga Mato-Grossense de Livre-Pensadores e passaram a publicar o jornal A Reacção (1909-1914), onde criticavam a Igreja Católica e D. Carlos.

${ }^{49} \mathrm{Nesse}$ contexto, as elites cuiabanas, que controlavam a política estadual, temiam a assimetria no desenvolvimento entre o Norte e o Sul de Mato Grosso. Enquanto o Norte permanecia estacionado, em termos demográfico e econômico, a região Sul recebia grande fluxo de migrantes brasileiros e imigrantes estrangeiros e se expandia a pecuária e a economia ervateira. 0 traçado da linha ferroviária Noroeste do Brasil foi alterado, em 1907, de Cuiabá para Porto Esperança, nas margens do rio Paraguai. A ferrovia, ao interligar Bauru a Porto Esperança, permitiria uma ligação rápida e direta com São Paulo e o Rio de Janeiro. A população cuiabana, por sua vez, continuava a depender da difícil navegação dos rios Cuiabá e Paraguai. Em decorrência, houve o incremento urbano e o aumento da importância econômica e política das cidades de Corumbá e Campo Grande, no Sul de Mato Grosso, enquanto Cuiabá passou a ser vista como uma cidade decadente e atrasada no caminho do progresso e da civilização. QUEIROZ, Paulo Roberto Cimó. Mato Grosso/Mato Grosso do Sul: divisionismo e identidades (um breve ensaio). In Revista Diálogos, Maringá, v. 10, n. 2, pp. 149-184, 2006, p. 156; GALETTI, Lylia da Silva Guedes. Sertão, fronteira, Brasil: imagens de Mato Grosso no mapa da civilização. Cuiabá: EdUFMT, Entrelinhas, 2012, pp. 312-317.
} 
Que o digam os que ainda se não esqueceram do explendor das mesmas festas religiosas que a intolerancia incoercivel de S. Ex $\mathrm{x}^{\mathrm{a}}$ só tem conseguido empallidecer, amortecendo de dia para dia no espirito dos seus diocesanos o sentimento religioso que por acaso ainda lhes restava. ${ }^{50}$

Em 1909, por meio de uma carta circular, Bavona elaborou 17 questões para obter informações sobre todas as circunscrições eclesiásticas, as gestões episcopais, sobretudo sobre as medidas práticas tomadas para restaurar a disciplina eclesiástica, combater os erros da modernidade, expandir as instituições católicas e tornar o catolismo presente na sociedade. O objetivo era conhecer suas singularidades e mapear as iniciativas episcopais, sobretudo a existência, ou não, de instituições católicas e as possibilidades de desmembrarem seus territórios. ${ }^{51} \mathrm{D}$. Carlos informou que a diocese de Cuiabá abrangia todo o estado de Mato Grosso, com extensão de 50,175 léguas quadradas, e que a população era de 157 mil católicos. Havia 17 paróquias, das quais cinco estavam vacantes pela escassez de clero, que era constituído de dois padres seculares e 34 regulares estrangeiros, pertencentes à Congregação Salesiana e às ordens franciscana e carmelita. D. Carlos mencionou que uma das dificuldades que enfrentava era a escassez de clero, e por isso não eram realizados retiros religiosos do clero, não havia sociedades de auxílio mútuo e instituições assistenciais (exceto o asilo Santa Rita), e as missões populares eram esporádicas. Como decorrência, expandiam-se a maçonaria, o positivismo, o espiritismo e o protestantismo, além dos ideais anticlericais e antirreligiosos. Esses concorrentes não foram vistos como ameaças, pois os matrimônios religiosos ainda superavam os civis, em uma proporção de 100 para 30, e por não haver apostasias em favor do protestantismo. As instituições católicas eram "o pequeno Seminário", que estava sob a direção dos terciários franciscanos, que "não florescia por falta de vocações", e os colégios católicos de Cuiabá, Poconé, Cáceres e Corumbá. Quanto às condições econômicas da mitra, "não poderiam ser mais penosas", sendo os recursos insuficientes para o sustento do bispo e de seu coadjutor. As rendas paroquiais eram poucas, e o clero seriam "todos pobríssimos"; por isso, não existiam conventos, igrejas e propriedades das ordens e congregações religiosas. Seu maior desafio era conseguir os recursos financeiros para desmembrar a diocese e criar novos

\footnotetext{
${ }^{50}$ BNDigital. Mais bispados. A Reacção: orgam da Liga Mato-Grossense de Livre Pensadores, n. 6, dezembro de 1909 , p. 132.

${ }^{51}$ A.A.V., Indici 1153, A.N.B., Busta 125, Fascicolo 618. Carta circular, 18 mar. 1909.
} 
bispados..$^{52}$ Para Bavona, essas informações respaldavam a necessidade de dividir a diocese de Cuiabá.

D. Carlos valorizava o censo de hierarquia e as barreiras hierárquicas, sendo cioso de sua posição social. A estrutura social é um sistema hierarquizado e desigual de poderes, privilégios ou não privilégios, determinados por relações econômicas, simbólicas, sociais e culturais. Os diferentes agentes lutam e dispõem de forças que dependem de sua pertença a campos objetivamente hierarquizados e de sua posição nos campos respectivos. ${ }^{53}$ As correspondências de D. Carlos demonstram o acatamento à autoridade e à pessoa dos representantes pontifícios, do cardeal Arcoverde e dos papas, por seus "altos", "dignos" e "honrosos cargos". Com relação ao núncio, sempre destacava sua elevada missão, sua sábia e prudente direção, sua autoridade como representante do papa e como dirigente dos destinos da Igreja Católica no Brasil. Ao mesmo tempo, considerava-se como o mais humilde dos bispos, com quem o núncio sempre encontraria docilidade, obediência, submissão e amor.

As posturas de D. Carlos com relação a D. Cirilo, hierarquicamente inferior, eram distintas. Por ser cioso de sua autoridade, tratava-o com descortesia e delegava apenas a função de realizar visitas pastorais. Em 10 de junho de 1909, D. Cirilo encaminhou à nunciatura um pedido de indulto que o autorizasse a residir fora da sede episcopal, onde julgasse necessário, a fim de tornar mais eficaz a assistência religiosa aos fiéis. ${ }^{54}$ Segundo Bavona, a condições em que D. Cirilo encontrava-se eram "tristíssimas", e o pedido foi motivado pelo "modo como foi tratado" por D. Carlos, ou seja, sem a "devida consideração" e "nenhuma liberdade". Para manter a "dignidade episcopal", teria sido "forçado" a residir distante da sé episcopal. ${ }^{55} \mathrm{O}$ pedido foi acolhido pela Santa Sé e publicado no dia 19 de abril de $1910 .^{56}$

Esse incidente gerou inúmeras críticas a D. Carlos, e Bavona ficou convicto de que era necessário intervir "o quanto antes", a fim de aumentar a hierarquia eclesiástica nas "vastas e inexploradas regiões" de Mato Grosso. A

\footnotetext{
${ }^{52}$ A.A.V., Indici 1153, A.N.B., Busta 125, Fascicolo 618. Carta de D. Carlos Luiz D'Amour para Alessandro Bavona, 15 jun. 1909 (tradução nossa).

${ }^{53}$ BOURDIEU, Pierre. O poder simbólico. Lisboa: Bertrand Brasil, 1998, p. 55.

${ }^{54}$ A.A.V., Indici 1153, A.N.B., Busta 125, Fascicolo 619. Carta de D. Cirilo de Paula Freitas, para Alessandro Bavona, 10 jun. 1909.

${ }^{55}$ A.A.V., Indici 1153, A.N.B., Busta 123, Fascicolo 610. Carta de Alessandro Bavona para Gaetando de Lai, $1^{\circ}$ fev. 1911; A.A.V., Indici 1153, A.N.B., Busta 125, Fascicolo 619. Carta de Alessandro Bavona para Raffaele Merry del Val, 12 maio 1909 (tradução nossa).

${ }^{56}$ A.A.V., Indici 1153, A.N.B., Busta 125, Fascicolo 619. Carta de Raffaele Merry del Val para Alessandro Bavona, 22 abr. 1909.
} 
divisão da diocese iria "promover o incremento da religião", pois tinha "uma extensão de 1.379.651 quilômetros quadrados, quase cinco vezes a Itália", e com apenas "200.000 habitantes". A baixa densidade demográfica criava desafios e "cuidados especiais", para tornar mais eficaz a assistência religiosa. Bavona também mencionou os cálculos realizados pelos salesianos acerca das populações indígenas "a serem evangelizadas", que seriam "cerca de quinhentos mil". ${ }^{77}$

A estratégia de Bavona para que D. Carlos não recuasse e para impulsioná-lo a prosseguir com o projeto de criação da província eclesiástica era tecer, de forma diplomática, inúmeros elogios às iniciativas de desmembrar a "vastíssima diocese", agradecendo-lhe as informações prestadas, as providências que estavam sendo encaminhadas e as notícias que enviava sobre os andamentos das comissões criadas para constituir o patrimônio diocesano. Destacava também as vantagens ao estado de Mato Grosso e a eternização do fato como sendo "uma das maiores glórias do seu pontificado". ${ }^{58} \mathrm{Em}$ um tom precavido e cauteloso, exercitava suas habilidades para estimular D. Carlos, ao mobilizar sua imagem pública oficial. Bavona argumentava que a divisão eternizaria sua gestão e glorificaria sua pessoa em razão das conquistas que empreendeu no campo da religião. Além disso, iria articular propagandas acerca de sua gestão, tanto em Mato Grosso quanto no Brasil, no Vaticano e no exterior, transformando-a em um monumento, não somente para seus contemporâneos, como também para a posteridade. Segundo Le Goff, os monumentos evocam o passado, perpetuam as recordações - voluntárias ou involuntárias - e são legados à memória coletiva, ou seja, são um produto da sociedade que os fabricou, segundo as relações de força daqueles que detinham o poder. ${ }^{59}$ Naquele contexto, a opinião social tinha peso significativo na boa sociedade, a partir da qual se procurava planejar e construir sua autoapresentação ostentatória para os contemporâneos e a posteridade.

Entre as estratégias mais eficazes de Bavona, para não criar a impressão de que era uma imposição da Santa Sé, foi a de fazer D. Carlos crer que era o protagonista da divisão da diocese, que, como núncio, não estaria interferindo em suas decisões e que seria o responsável por todos os protocolos e as exigências burocráticas para elaborar o projeto que seria enviado à Cúria Romana. D.

\footnotetext{
${ }^{57}$ A.A.V., Indici 1153, A.N.B., Busta 125, Fascicolo 619. Carta de Alessandro Bavona para Raffaele Merry del Val, 12 maio 1909 (tradução nossa).

${ }^{58}$ A.A.V., Indici 1153, A.N.B., Busta 122, Fascicolo 601. Cartas de Alessandro Bavona para D. Carlos Luiz D’Amour, 6 jul. 1909 e 15 mar. 1910 (tradução nossa).

${ }^{59}$ LE GOFF, Jacques. História e memória. Campinas: Editora da Unicamp, 1990, pp. 535-549.
} 
Carlos, por sua vez, sempre considerou e divulgou como sendo de sua autoria a iniciativa de dividir a diocese de Cuiabá. ${ }^{60} \mathrm{Na}$ verdade, Bavona redigiu o projeto e fez a maioria dos encaminhamentos. Em uma correspondência endereçada a D. Arcoverde, expôs sua tática em tom sarcástico: “Telegraphei ao Snr. Arcebispo de Cuyabá congratulando-me pelo trabalho que elle diz ter iniciado para crear duas dioceses tiradas da actual immensa diocese de Cuyabá." ${ }^{61}$ As redes de informações e comunicações seguiam hierarquias, tendo com D. Arcoverde liberdades para confidenciar e fazer apreciações críticas. Com D. Carlos, as relações eram distintas, sendo diplomáticas, conciliadoras, cautelosas, precavidas e amistosas.

D. Carlos, submetendo-se, agradecia as "bondosas pressões" para desmembrar a diocese de Cuiabá e as "felicitações" por seu "intento de crear duas Dioceses desmembradas desta confiada a meus cuidados". As pressões de Bavona eram vistas como um "grato dever" e uma obrigação, pois partiam de uma autoridade hierarquicamente superior. Com relação aos atrasos em relação às informações e aos dados solicitados por Bavona, utilizava-se de estratégias protocolares, ou seja, problemas de saúde e outros "justos motivos", que eram prontamente aceitos. ${ }^{62}$ Nas correspondências, D. Carlos esmerava-se em demonstrar seu senso de dever com o núncio, sua gratidão pelos elogios, reafirmando sua submissão hierárquica e as relações de confiança, amizade e cumplicidade.

Em 29 de outubro de 1909, D. Carlos definiu os títulos das futuras dioceses, quais igrejas seriam elevadas a catedral e seu território:

O titulo da Igreja de Corumbá "Santa Cruz" e o de Caceres é "S. Luiz". A Diocese de Corumbá constará das Parrochias de Santa Cruz de Corumbá (cidade Episcopal ou sede da Diocese), S. José de Herculânea, N. Senhora do Carmo de Miranda, Santa Rita de Nioac, e Sant'Anna do Paranahyba; e a Diocese de Caceres constará das Parochias de S. Luiz de Caceres (Cidade Episcopal ou Sede da Diocese), N. Senhora do Rosario de Pocone, N. Senhora do Livramento e SS. Trindade de Matto Grosso.

A Igreja de Corumbá é optima e tem proporções para ser elevada a Cathedral, a de Caceres, que é de três naves está ainda para ser

\footnotetext{
${ }^{60}$ A.A.V., Indici 1153, A.N.B., Busta 122, Fascicolo 601. Cartas de D. Carlos Luiz D’Amour para Alessandro Bavona, 8 maio 1910.

${ }^{61}$ A.A.V., Indici 1153, A.N.B., Busta 123, Fascicolo 610. Carta de D. Joaquim Arcoverde de Albuquerque Cavalcanti para Alessandro Bavona, 11 jun. 1908 (tradução nossa, grifo nosso).

${ }^{62}$ A.A.V., Indici 1153, A.N.B., Busta 122, Fascicolo 601. Carta de D. Carlos Luiz D’Amour para Alessandro Bavona, núncio apotólico, 29 out. 1909 (tradução nossa).
} 
concluída, terminada porem que sea essa igreja, será superior à de Corumbá. ${ }^{63}$

As duas comissões pró-dioceses não desempenharam suas funções de forma satisfatória. A de Corumbá teve os trabalhos interrompidos pelos conflitos políticos no sul de Mato Grosso e com a posse de dois membros (inclusive do governador, que havia renunciado ao mandato) na Câmara dos Deputados, no Rio de Janeiro. ${ }^{64}$ Joaquim Augusto da Costa Marques, que presidia a de Cáceres, informou "com pesar" a D. Carlos que "n'esta cidade nada se tem feito até hoje relativamente a acquisição de fundos para a erecção deste Bispado", pois havia se mudado para o Rio de Janeiro, e "não tem sido possível ocupar-me convenientemente d'esse magno assunto", e que os demais membros tinham se exonerado do encargo. Marques reconheceu que não deveria ter aceitado a incumbência, "pois devia prever a impossibilidade em que se achava de bem corresponder a expectativa" e que "nada de importante poderei fazer nas minhas curtas passagens por aqui". Por fim, sugeria a nomeação de outros membros. ${ }^{65} \mathrm{D}$. Cirilo foi incumbido de retomar os trabalhos das comissões, porém não teve sucesso. D. Carlos contribuiu com a doação de várias joias, que foram doadas. Essa ação demonstrava desprendimento e seu consentimento à divisão da diocese. ${ }^{66}$

A criação da província eclesiástica era vista pelas elites mato-grossenses como um acontecimento grandioso, que demonstrava a proteção e a intervenção da Santa Sé em promover o desenvolvimento religioso. O status de ser sede episcopal era um dos indicadores de civilidade e progresso, em contraposição aos estigmas de fronteira-sertão, outro espaço geográfico, simbólico e social, um "mundão" abandonado, terras que não se acabavam e que só Deus conhecia. Nesse sentido, a criação de uma diocese foi um projeto conservador eclesiástico e civil, que se unia em torno de interesses comuns, favorecendo a expansão institucional e sendo reconhecida como legítima.

A inexistência de patrimônios prévios e de rendas para o sustento dos bispos fez com que a Santa Sé se adequasse às singularidades econômicas, culturais, políticas e religiosas do Brasil. As exigências jurídicas e financeiras

\footnotetext{
${ }^{63}$ Idem.

${ }^{64}$ Idem.

${ }^{65}$ BNDigital. Governo do bispado. Bispado de Corumbá e S. Luiz de Caceres. A Cruz: Órgão da "Liga Catholica Brasileira" de Matto Grosso, Cuiabá, ano I, n. 5, 15 jul. 1910, p. 1.

${ }^{66}$ S.S., S.RR.SS., A.S., AA.EE.SS., Brasile III, Anno 1911, Rubrica 251, Fascicolo 4. Carta de D. Carlos Luiz D’Amour para Alessandro Bavona, 29 out. 1909.
} 
estabelecidas pelo Concílio de Trento e pelo Concilio Plenário Latino-Americano foram relativizadas. As comissões de Corumbá e Cáceres não conseguiram arrecadar $150 \$ 0000$ (cento e cinquenta mil réis) de capital de raiz, não havia residência episcopal e as obras da catedral de Cáceres ainda não tinham sido concluídas. Posteriormente, outras irregularidades somaram-se a essas: não havia seminário, capítulo catedrático, funcionários na cúria diocesana, procuradoria da mitra, intendência e obras assistenciais.

Bavona, ao encaminhar o projeto à Secretaria de Estado, esclareceu que o estado de Mato Grosso tinha um território "cinco vezes maior que o da Itália", de $1.500 .000 \mathrm{~km}^{2}$, em sua maioria inexplorado economicamente. Quanto à população, afirmava que "não existia nenhum censo", mas que seriam cerca de 200 mil habitantes, excluídos os indígenas, que foram estimados em 500 mil. Os mato-grossenses e os indígenas estariam sem assistência religiosa pela escassez de clero, e não haveria possibilidade de reverter esse cenário. Segundo Bavona, desde a criação da prelazia, em 1745, não houve um incremento religioso significativo, exceto após a chegada dos salesianos, que administravam paróquias, colégios e missões entre os indígenas; dos franciscanos, que dirigiam o seminário diocesano; e dos carmelitas, que atuavam na paróquia de Corumbá. Para Bavona, haveria nessa região, "distante e abandonada", um arcebispo e dois bispos, que "se ajudarão mutuamente com o conselho e com o trabalho". Por fim, concluía: "Basta olhar o mapa geográfico do Brasil para entender a importância e a urgência da proposta apresentada", pois haveria melhorias na administração eclesiástica em Mato Grosso. Ao estabelecer analogias com a construção de um prédio, defendia que esta deveria ser realizada de alvenaria, para maior solidez, e em partes. Ou seja, era necessário intervir para alterar um cenário considerado desfavorável. ${ }^{67}$

Bavona anexou ao projeto a carta de D. Carlos, em que consentia no desmembramento do "vasto território" da diocese de Cuiabá. Para que não houvesse um estranhamento do pequeno número de paróquias, pois Corumbá teria cinco, e Cáceres, apenas quatro, argumentou que se justificava pela grande extensão territorial e pela baixa densidade demográfica, mas que logo seriam divididas e seriam confiadas ao clero secular e regular. 0 núncio minimizou a interrupção dos trabalhos da comissão instituída para prover um patrimônio diocesano, alegando a contribuição dos fiéis e a possibilidade de a referida comissão atingir seus objetivos. Por fim, argumentava que a "experiência ensina isso; as dioceses recém-fundadas logo dobraram o número

${ }^{67}$ S.S., S.RR.SS., A.S., AA.EE.SS., Brasile III, Anno 1911, Rubrica 251, Fascicolo 4. Carta de Alessandro Bavona para Raffaele Merry del Val, 22 jan. 1910 (tradução nossa). 
de sacerdotes e despertaram não poucas vocações eclesiásticas". Para bispo de Corumbá, pretendia nomear D. Cirilo, bispo coadjutor de D. Carlos, e, para Cáceres, um padre "abnegado" e "zeloso". ${ }^{68}$

Em 24 de maio de 1910, Bavona foi informado de que Pio X tinha autorizado a criação da província eclesiástica de Cuiabá, para aumentar, em larga escala, a presença da Igreja Católica na região, por meio do incremento do número de paróquias, de instituições católicas, de missões entre os indígenas e do clero regular e secular. Havia a expectativa, confirmada por Bavona, de que seria constituído um patrimônio diocesano, que as extensas paróquias seriam divididas e de que todas seriam providas. Ou seja, de que "as dificuldades seriam superadas com o tempo". ${ }^{69}$

Em 5 de março, o núncio foi informado de que o papa Pio X tinha aprovado o projeto e determinava a confecção da bula. A Santa Sé erigiu as novas circunscrições eclesiásticas pela bula Novas Constituere, firmada em 5 de abril de 1910, que subtraiu a sé episcopal de Cuiabá do arcebispado de São Sebastião do Rio de Janeiro e elevou-a à dignidade e honra de sé arquiepiscopal, tendo como sufragâneas as dioceses de Santa Cruz de Corumbá e São Luiz de Cáceres. D. Carlos foi elevado à dignidade e honra de arcebispo..$^{70} \mathrm{~A}$ província eclesiástica de Cuiabá abrangia $1.374 .651 \mathrm{~km}^{2}$, com uma população, em 1910, de 171.672 habitantes. O território da diocese de São Luiz de Cáceres era de mais de $350.279,9 \mathrm{~km}^{2}$; o da diocese de Santa Cruz de Corumbá, de $450.000 \mathrm{~km}^{2}$; e o da arquidiocese de Cuiabá, $573.371,1 \mathrm{~km}^{2}$. A diocese de Corumbá abrangia as paróquias de "Santa Cruz de Corumbá, S. José de Herculânea, N. S. do Carmo de Miranda, Santa Rita de Nioac e Sant'Ana do Paranahyba", e a de Cáceres, as paróquias de "S. Luiz de Caceres, N. Senhora do Rosario de Poconé, N. Senhora do Livramento, S. S. Trindade de Matto Grosso". ${ }^{71}$

Na bula, Pio X considerou as dificuldades que D. Carlos enfrentava para exercer o múnus episcopal em razão das distâncias geográficas e da dispersão da população, sendo "impossível que possa ser governada e administrada por um só bispo", que vivia isolado dos demais membros do episcopado. Aumentar

\footnotetext{
${ }^{68}$ Idem.

${ }^{69}$ S.S., S.RR.SS., A.S., AA.EE.SS., Brasile III, Anno 1911, Rubrica 251, Fascicolo 4. Carta de Scipione Tecehi para Alessandro Bavona, 24 fev. 1910 (tradução nossa).

${ }^{70} \mathrm{~A}$ adoção de São Luiz de Cáceres deveu-se à necessidade de diferenciar da diocese de Cáceres, nas Filipinas. A.A.V., Indici 1289, Congregazione Concistoriale, Positiones, Cuiabá (Cuiaben) in Brasile I, dal 1909 a 1921. Prot. n. 388/1909. Carta de Merry del Val para Gaetano de Lai, 8 mar. 1917.

${ }^{71}$ PIO X. Novas Constituere (1910). A.A.V., Indici 1153, A.N.B., Busta 122, Fascicolo 601. Tit. XI: Diocesi Erezione di uma provinzia eccl. Nello Stato di Matto Grosso (tradução nossa).
} 
a hierarquia eclesiástica em Mato Groso iria "facilitar o intercâmbio dos bispos com o arcebispo", e haveria "maior celeridade no andamento dos negócios eclesiásticos". Quanto ao patrimônio, ainda não constituído, Pio X apelava à generosidade dos católicos. ${ }^{72}$

D. Carlos foi informado da aprovação no dia 8 de maio de 1910, quando expressou sua gratidão ao papa pela "especial graça de ter aprovado a minha proposta". A notícia da criação da província eclesiástica foi divulgada pela imprensa e, segundo D. Carlos, a notícia foi bem recebida e "logo espalhou-se nesta capital". Em 25 de maio de 1911, publicou uma carta pastoral, na qual apresentava a criação da província eclesiástica como um "auspicioso acontecimento". Também manifestava sua preocupação com o ínfimo patrimônio que foi arrecadado, admoestando os habitantes de Cáceres "que ainda nada fizeram relativamente á erecção daquella Diocese", e esperava que concluíssem as obras na catedral e que concorressem para a manutenção do bispo. ${ }^{73}$

Bavona, ao remeter a bula papal a D. Carlos, felicitou-o pelo zelo apostólico e considerou o título de arcebispo como um "justo galardão concedido" e um "merecimento". ${ }^{74}$ A divisão iria "promover o incremento da religião nesse Estado de Matto Grosso, e que constituirá a mais bella gloria do seu longo e fecundo pontificado". Bavona, ao elogiá-lo, mantinha D. Carlos sob seu controle, permitindo que novas intervenções da Santa Sé pudessem ser realizadas.

Para os editores do jornal católico A Cruz, Pio X, ao elevar D. Carlos a arcebispo, reconhecia os méritos e as conquistas da sua gestão episcopal e a sua dedicação à Igreja Católica. A nomeação, portanto, seria um condigno prêmio às suas benemerências pastorais. ${ }^{75} \mathrm{D}$. Carlos, apesar de estar lisonjeado e orgulhoso, considerou que foi agraciado com a elevada posição hierárquica apesar da sua "insufficiencia e nenhum merecimento". ${ }^{76}$ Demonstrar humildade fazia parte dos protocolos para reforçar sua fidelidade e submissão ao papa, sua

\footnotetext{
${ }^{72}$ Idem.

${ }^{73}$ D'AMOUR, D. Carlos Luiz. Carta Pastoral do Exmo. e Revm. Sr. D. Carlos Luiz d'Amour, Arcebispo Metropolitano de Cuiabá, anunciando a erecção da Provincia Eclesiastica de Cuiabá. A Cruz: Órgão da “Liga Catholica Brasileira” de Matto Grosso, Cuiabá, ano II, n. 31, 9 jul. 1911, p. 3.

${ }^{74}$ BNDigital. Carta oficial, com que o Exmº e Rmº. Senr. Nuncio Apostolico enviou á Sua Excia. e Rmº o Senr. D. Carlos arcebispo metropolitano, a bulla e decreto executivo, erigindo a Provincia Ecclesiastica de Cuiabá. A Cruz: Órgão da "Liga Catholica Brasileira" de Matto Grosso, Cuiabá, ano II, n. 31, 9 jul. 1911, p. 1, grifo nosso. ${ }^{75}$ BNDigital. O Sr. arcebispo metropolitano. A Cruz: Órgão da "Liga Catholica Brasileira" de Matto Grosso, Cuiabá, ano II, n. 27, 11 jun. 1911, p. 2.

${ }^{76}$ BNDigital. Governo do arcebispado. Carta pastoral. Do Exmo. Sr. D. Carlos Luiz d'Amour arcebispo de Cuiabá, annunciando a creação da provincia ecclesiastica de Cuiabá. A Cruz: Órgão da "Liga Catholica Brasileira" de Matto Grosso, Cuiabá, ano II, n. 31, 9 jul. 1911, p. 3.
} 
sabedoria, sua boa educação e urbanidade. A reportagem enaltecia também as suas qualidades prodigiosas e construía uma imagem oficial sacralizada, divina, encantada, eficiente, sábia, culta e educada com o objetivo de difundir respeito e admiração entre os diocesanos. Havia a preocupação de propagar a imagem de que era amado pelo povo por suas virtudes de bom pastor e por contribuir para o engrandecimento do catolicismo em Mato Grosso:

O povo mattogrossense em sua fé religiosa e em o seu alto civismo sabe amar e venerar o illustre personagem que desde longos annos guia as suas almas para o céo e acompanha com mais alto interesse a evolução deste pedaço de terra brasileira para o futuro de grandeza que o aguarda no tempo. ${ }^{77}$

Em 1910, por causa da atuação de Bavona, o Brasil estava dividido em oito províncias eclesiásticas (Bahia, Rio de Janeiro, Pará, Mariana, São Paulo, Cuiabá, Porto Alegre e Olinda), tendo sido seis criadas pelo papa Pio X, e 29 bispados, uma prelazia, três prefeituras apostólicas e uma missão. A hierarquia eclesiástica era constituída por oito arcebispos, 29 bispos, dois prelados nullius e três prefeitos apostólicos.

\section{Considerações finais}

A Santa Sé e o episcopado, em um contexto de profundas transformações econômicas, sociais, políticas e culturais da sociedade brasileira e internacional, e para sobreviver e adaptar-se a elas, investiram em estratégias para tornar mais eficaz seu poder pastoral, entre elas a de dinamizar sua presença na sociedade e de fortalecer-se perante o Estado laico por meio da ampliação das jurisdições eclesiásticas, ou seja, de paróquias, prefeituras apostólicas, missões, prelazias, dioceses e arquidioceses. Quanto menor sua extensão territorial, mais eficazes seriam sua governabilidade, o controle e a gestão dos indivíduos e do corpo social e a implementação de tecnologias do poder. Nesse sentido, a Igreja Católica e o Estado moderno tinham os mesmos interesses e práticas para a regulação e o controle dos territórios e das populações, estando associados na construção e na ascensão da sociedade biopolítica e, posteriormente, da sociedade de controle. ${ }^{78}$ Foucault define governabilidade como "o conjunto constituído pelas instituições, os procedimentos, análises

\footnotetext{
${ }^{77}$ BNDigital. O Exmo. Dr. arcebispo D. Carlos Luiz d'Amour. A Cruz: Órgão da "Liga Catholica Brasileira" de Matto Grosso, Cuiabá, ano I, n. 15, 15 dez. 1910, p. 2.

${ }^{78}$ DELEUZE, Gilles. Post scriptum sobre as sociedades de controle. In G. Deleuze. Conversações. Rio de Janeiro: 34 Letras, 1992. pp. 219-226; FOUCAULT, Michel. Em defesa da sociedade. São Paulo: Martins Fontes, 2000.
} 
e reflexões, os cálculos e as táticas que permitem exercer essa forma bem específica, embora muito complexa, de poder que tem por alvo principal a população", ou seja, é o "'governo' sobre todos os outros - soberania, disciplina - e que trouxe, por um lado, o desenvolvimento de toda uma série de aparelhos específicos de governo" e de "saberes". ${ }^{79}$

A Santa Sé, como tática de governabilidade para ordenar o território e a sociedade, analisava três critérios: a superfície territorial, a população e a densidade demográfica. O objetivo era desmembrar as dioceses mais extensas e as que tinham maior ou menor densidade demográfica, para ampliar a presença da Igreja Católica na sociedade e entre as populações indígenas. A escassez de rendas e recursos fez com que a Igreja se adequasse à realidade brasileira e diminuísse as exigências jurídicas e financeiras estabelecidas pelo Concílio de Trento e pelo Concílio Plenário Latino-Americano. As dioceses de Corumbá e Cáceres foram criadas sem o capital de raiz exigido, tais como catedral e palácio episcopal - patrimônio que garantisse a sobrevivência do bispo e a implantação de obras filantrópicas e educacionais, mesmo com clero escasso. Posteriormente, outras irregularidades somaram-se a essas: muitas jurisdições eclesiásticas não tinham seminário, capítulo catedrático e obras assistenciais em razão da escassez de clero e recursos.

Muitos bispos, como D. Carlos, eram contrários aos desmembramentos dos territórios diocesanos e não tomavam a iniciativa, apesar dos apelos dos papas Leão XIII e Pio X. A estratégia do núncio Alessandro Bavona, diante da personalidade e do estilo de mando de D. Carlos, foi diplomática, conciliadora, precavida, para que não desistisse da divisão da diocese e para que acreditasse que a iniciativa era sua. Coube a D. Carlos constituir as comissões para prover de patrimônio, fornecer informações sobre as futuras dioceses e designar seus territórios e edifícios religiosos que seriam elevados a catedral. Bavona, por sua vez, redigiu o processo de divisão, enviou-o à Santa Sé e acompanhou sua tramitação até a aprovação papal. Enfim, o núncio obteve a vitória, reafirmando sua capacidade de liderança e excelência como diplomata. D. Carlos, por sua vez, demonstrava a habilidade de reinterpretar a realidade a seu favor.

Com a criação das dioceses de Corumbá e Cáceres e a elevação de Cuiabá a arquidiocese, esperava-se que fossem superados seus principais problemas: a soberania exclusiva de D. Carlos sobre as terras mato-grossenses, o pequeno número de paróquias e de edifícios religiosos (igrejas e capelas), bem como a escassez de clero e de rendas, inclusive para garantir a sobrevivência dos

${ }^{79}$ FOUCAULT, Michel. Segurança, território, população. São Paulo: Martins Fontes, 2008, pp. 143-144. 
bispos, barrar a expansão das religiões concorrentes e ampliar a presença da Igreja Católica entre as populações indígenas.

\section{Referências}

AQUINO, Mauricio de. Modernidade republicana e diocesanização do catolicismo no Brasil: a construção do bispado de Botucatu no sertão paulista (1989-1923). Tese (Doutorado em História) - Universidade Estadual Paulista, Assis, 2012.

BOURDIEU, Pierre. O poder simbólico. Lisboa: Bertrand Brasil, 1998.

BUENO, Francisco Antonio Pimenta. Memória justificativa dos trabalhos que foi encarregada a província de Mato Grosso segundo as instruções do Ministério da Agricultura, de 27 de março de 1879. Rio de Janeiro: Nacional, 1880.

D’AMOUR, D. Carlos Luiz. Carta Pastoral do Exmo. e Revm. Sr. D. Carlos Luiz d'Amour, Arcebispo Metropolitano de Cuiabá, anunciando a erecção da Provincia Eclesiastica de Cuiabá. A Cruz: Órgão da "Liga Catholica Brasileira" de Matto Grosso, Cuiabá, ano II, n. 31, 9 jul. 1911, p. 3. Disponível em: < http://memoria.bn.br/ docreader/765503/129 >. Acesso em: 24 abr. 2020.

DELEUZE, Gilles. Post scriptum sobre as sociedades de controle. In: G. Deleuze. Conversações. Rio de Janeiro: 34 Letras, 1992. p. 219-226.

DUTRA NETO, Luciano. Das terras baixas da Holanda às montanhas de Minas: uma contribuição à história das missões redentoristas, durante os primeiros trinta anos de trabalho em Minas Gerais. Tese (Doutorado em História) - Universidade Federal de Juiz de Fora, Juiz de Fora, 2006.

ELIAS, Norbert. A sociedade dos indivíduos. Rio de Janeiro: Jorge Zahar, 1994.

FOUCAULT, Michel. Em defesa da sociedade. São Paulo: Martins Fontes, 2000.

FOUCAULT, Michel. Segurança, território, população. São Paulo: Martins Fontes, 2008.

FOUCAULT, Michel. Vigiar e punir: história da violência nas prisões. Petrópolis:

Vozes, 1987.

GALETTI, Lylia da Silva Guedes. Sertão, fronteira, Brasil: imagens de Mato Grosso no mapa da civilização. Cuiabá: EdUFMT, Entrelinhas, 2012.

LE GOFF, Jacques. História e memória. Campinas: Editora da Unicamp, 1990. 
MANOEL, Ivan Aparecido. A criação de paróquias e dioceses no Brasil no contexto das reformas ultramontanas e da ação católica. In: SOUZA, Rogério Luiz de; OTTO, Clarícia (org.). Faces do catolicismo. Florianópolis: Insular, 2008, pp. 41-59.

MARIN, Jérri Roberto (org.). Circunscrições eclesiásticas católicas no Brasil: articulações entre Igreja, Estado e Sociedade. Campo Grande, Ed. da UFMS, 2021. Disponível em: https://repositorio.ufms.br/handle/123456789/3660.

MARIN, Jérri Roberto. A Santa Sé e a criação de novas circunscrições eclesiásticas em 1892. In Revista Brasileira de História das Religiões, Maringá, ano XIV, v. 14, n. 40, maio/ago., pp. 221-250, 2021.

MARIN, Jérri Roberto. Reflexões sobre a imprensa católica no Brasil. In Religião e Sociedade, Rio de Janeiro, v. 38, n. 3, set./dez., pp. 197-217, 2018.

MICELI, Sergio. A elite eclesiástica brasileira. Rio de Janeiro: Bertrand, 1988.

MOURA, Carlos André Silva de; CABRAL, Newton Darwin de Andrade.

Reorganização eclesiástica em Pernambuco: o processo de formação das Dioceses de Garanhuns, Nazaré e Pesqueira (1910-1918). In Revista Brasileira de História das Religiões, Maringá, v. 13, n. 38, set./dez., pp. 145-163, 2020.

QUEIROZ, Paulo Roberto Cimó. Mato Grosso/Mato Grosso do Sul: divisionismo e identidades (um breve ensaio). In Revista Diálogos, Maringá, v. 10, n. 2, pp. 149-184, 2006.

SANTIROCCHI, Ítalo Domingos. Uma questão de revisão de conceitos: romanização - ultramontanismo - reforma. In Temporalidades, Belo Horizonte, v. 2, n. 2, pp. 2433, 2010.

Artigo recebido para publicação em 24/07/2021 Artigo aprovado para publicação em 09/08/2021 